\title{
RESEARCH OF BUSINESS PROCESSES \\ OF RETAIL TRADE ENTERPRISES BY QUALITY ANALYSIS METHODS
}

\author{
N. Mikitenko, V. Dubinina \\ Kyiv National University of Trade and Economics
}

\begin{tabular}{|c|c|}
\hline Key words: & ABSTRACT \\
\hline $\begin{array}{l}\text { Business processes } \\
\text { Retail business } \\
\text { Business process } \\
\text { management } \\
\text { Methods of qualitative } \\
\text { analysis } \\
\text { Management problems }\end{array}$ & $\begin{array}{l}\text { The article defines the factors hindering the development of } \\
\text { the trade sector in Ukraine. The essence of business processes } \\
\text { of enterprises is revealed. The roles of officials involved in the } \\
\text { implementation of business processes of enterprises, are descri- } \\
\text { bed namely: business process owners, owners of business } \\
\text { process resources, business process implementers. The list of } \\
\text { main business processes of retail enterprises is presented, taking }\end{array}$ \\
\hline $\begin{array}{l}\quad \text { Article history: } \\
\text { Received 12.03.2018 } \\
\text { Received in revised form } \\
\text { 29.03.2018 } \\
\text { Accepted } 09.04 .2018 \\
\end{array}$ & $\begin{array}{l}\text { into account their orientation on satisfying the interests and } \\
\text { preferences of the last users (external) consumers and } \\
\text { increasing the consumer value., Food retailers of several } \\
\text { formats are selected for research: supermarkets, "shops near the } \\
\text { house", discounters. The sample consisted of thirteen retailers, }\end{array}$ \\
\hline $\begin{array}{l}\text { Corresponding author: } \\
\text { N. Mikitenko } \\
\text { E-mail: } \\
\text { npnuht@ukr.net }\end{array}$ & $\begin{array}{l}\text { located in different geographical regions of Kyiv, which mainly } \\
\text { sell food products. } \\
\text { The analysis of the basic business processes was conducted } \\
\text { taking into account various formats of retail enterprises using } \\
\text { the methods of qualitative analysis. Summarized results of } \\
\text { expert evaluation of the level of problem of business processes } \\
\text { of retail trade enterprises are presented. The main problems that } \\
\text { arise in the management of business processes of food retail } \\
\text { enterprises by using the expert evaluation method is identified. } \\
\text { To simplify the study four groups of key business processes } \\
\text { of the company were formed: trade and technological, business } \\
\text { processes of quality improvement, procurement. The modern } \\
\text { tools for solving problems of business processes management } \\
\text { of retailers are offered, which will increase their efficiency / } \\
\text { effectiveness and increase the competitiveness of retail } \\
\text { enterprises in an aggressive market medium. }\end{array}$ \\
\hline
\end{tabular}

DOI: $10.24263 / 2225-2924-2018-24-2-12$

\section{ДОСЛІДЖЕННЯ БІЗНЕС-ПРОЦЕСІВ ПІДПРИЄМСТВ РОЗДРІБНОї ТОРГІВЛІ ЗА ДОПОМОГОЮ МЕТОДІВ ЯКІСНОГО АНАЛІЗУ}

\author{
Н.В. Микитенко, В.В. Дубініна \\ Київський національний торговельно-економічний університет
}

У статті визначено фактори, шо гальмують розвиток торговельної галузі в Украӥні. Розкрито сутність бізнес-процесів підприємств. Охаракте- 
ризовано ролі посадових осіб, які беруть участь у реалізації бізнес-процесів підприємств, а саме: власників бізнес-прочесів, власників ресурсів бізнеспрочесів, виконавців бізнес-прочесів. Представлено перелік основних бізнеспрочесів підприємств роздрібної торгівлі з урахуванням їх спрямованості на задоволення інтересів і вподобань кінцевих (зовнішніх) споживачів та нарощування споживчої иінності й вартості. Для дослідження обрано продовольчі підприсмства роздрібної торгівлі декількох форматів: супермаркети, «магазини біля дому», дискаунтери. Вибіркову сукупність склало тринадияять підприємств роздрібної торгівлі, щзо розташовані в різних географічних районах м. Києва та реалізують переважно продовольчі товари.

Проведено аналіз основних бізнес-процесів з урахуванням різних форматів підприємств роздрібної торгівлі з використанням методів якісного аналізу. Наведено узагальнені результати експертного оцінювання рівня проблемності бізнес-процесів підприємств роздрібної торгівлі. Ідентифіковано основні проблеми, щзо виникають при управлінні бізнес-процесами продовольчих підприємств роздрібної торгівлі иляхом використання методу експертного очінювання.

Для спрощуення дослідження сформовано чотири групи основних бізнеспрочесів підприємств: торговельно-технологічні, бізнес-процеси поліпшення якості, закупівельні. Запропоновано сучасні інструменти вирімення проблем управління бізнес-процесами підприємств роздрібної торгівлі, щзо дають змогу підвищити їхню ефективність/результативність, а також конкурентоспроможність в агресивному ринковому середовищі.

Ключові слова: бізнес-процеси, підприємство роздрібної торгівлі, управління бізнес-процесами, методи якісного аналізу, проблеми управління.

Постановка проблеми. Дестабілізуючі процеси, що виникли в національній економіці, негативно вплинули на функціонування підприємств роздрібної торгівлі. Зокрема, за даними Державної служби статистики України, протягом 2014-2016 рр. відбулося скорочення кількості підприємств роздрібної торгівлі майже вдвічі, зменшення обсягів роздрібного товарообороту на $19 \%$, зростання частки збиткових підприємств роздрібної торгівлі на $5 \%$ [1-3]. У той же час має місце зниження індексу споживчих настроїв, окремі підприємства роздрібної торгівлі втрачають свої конкуренті позиції у боротьбі за покупців, а потенціал бізнес-процесів використовується ними неповною мірою. У зв'язку з цим виникає об'єктивна необхідність проведення аналізу бізнес-процесів як фундаменту функціонування підприємств 3 метою виявлення резервів удосконалення діяльності та підвищення конкурентоспроможності підприємств роздрібної торгівлі.

Аналіз останніх досліджень і публікацій. Дослідження підприємств роздрібної торгівлі та використання концепції ВРМ (управління бізнес-процесами) не втрачають актуальності у працях багатьох сучасних науковців. Так, діяльність підприємств роздрібної торгівлі є предметом наукових праць таких дослідників, як І.О. Бланк [4], С.І. Бай [5], Б. Берман [6], К. Шредер [7]. У свою чергу, управління бізнес-процесами привертає увагу таких вчених, як 
А.В. Шеєр [8], К.І. Редченко [9], В.Н. Парсяк [10]. Враховуючи значущість отриманого наукового доробку, відмітимо, що недостатньо вивченою на сьогодні залишається діяльність продовольчих підприємств роздрібної торгівлі. У зв'язку з цим пропонуємо дослідити бізнес-процеси продовольчих підприємств роздрібної торгівлі м. Києва та запропонувати заходи підвищення їх ефективності.

Метою статті $є$ дослідження поточного стану бізнес-процесів підприємств роздрібної торгівлі м. Києва з використанням таких методів якісного аналізу, як метод ідентифікації проблемних бізнес-процесів і причин зниження їх ефективності, порівняльний аналіз бізнес-процесів, метод експертного оцінювання, що дасть змогу прийняти ефективні рішення для покращення роботи досліджуваних підприємств.

Викладення основних результатів дослідження. Підприємства роздрібної торгівлі відіграють важливу роль у процесі суспільного відтворення. За допомогою своїх бізнес-процесів вони задовольняють матеріальними і нематеріальними благами існуючі потреби населення, створюють пропозицію та впливають на споживачів. Бізнес-процеси обмежені простором і часом, реалізують цілі підприємств та створюють/забезпечують обмін цінністю на підприємствах.

Зазначимо, що бізнес-процеси на підприємствах роздрібної торгівлі не відбуваються відокремлено від працівників. Кожен співробітник підприємства має права, обов'язки та бере участь у реалізації життєдіяльності бізнес-процесу, відповідаючи при цьому за отриманий результат бізнес-процесу. Крім цього, у науковій літературі з управління співробітників підприємств роздрібної торгівлі залежно від їх ролі у виконанні бізнес-процесів поділяють на власників бізнес-процесів, власників ресурсів, виконавців бізнес-процесів [11; 12]. Так, власник ресурсів бізнес-процесу — відповідальна особа (або підрозділ) за ресурси, необхідні для виконання бізнес-процесів. Вона складає бюджети, розраховує вартість і кількість ресурсів. Власниками ресурсів бізнеспроцесів на підприємствах роздрібної торгівлі, зазвичай, $є$ фінансовий, бухгалтерський відділи, які розподілять грошові потоки по всьому підприємству. У той же час логістичний підрозділ, відділ персоналу можуть виступати як власники товарно-матеріальних і людських ресурсів, що забезпечують реалізацію торговельно-технологічних бізнес-процесів підприємств. Паралельно власник бізнес-процесу — відповідальна особа, керівник, що організує виконання бізнес-процесу, розпоряджається отриманими ресурсами, визначає цілі бізнес-процесів і слідкує за їх досягненням, забезпечує розвиток бізнеспроцесу та поліпшує його якість, формує команду із професіоналів-виконавців, націлену на результат. Прикладом власників бізнес-процесів на підприємствах роздрібної торгівлі можуть бути керівники функціональних структур: керівник логістичного відділу, керівник відділу маркетингу, керівник відділу продажів. При виконанні наскрізних бізнес-процесів призначаються відповідальні особи, які знаходяться поза структурними підрозділами підприємства та повністю керують такими бізнес-процесами від початку до кінця. Тоді як виконавець бізнес-процесу - посадова особа, що має права і обов'язки та виконує одну або декілька операції в конкретних бізнес-процесах підприємств. 
У свою чергу бізнес-процеси слугують своєрідним барометром підприємств роздрібної торгівлі, адже, аналізуючи їх, керівництво отримує інформацію щодо фактичного стану діяльності підприємств, ідентифікує основні проблеми, що знижують показники ефективності діяльності та задоволеності споживчого попиту. У контексті цього проаналізуємо бізнес-процеси підприємств роздрібної торгівлі й визначимо перспективи їх розвитку.

Ринок роздрібної торгівлі представлений продовольчими (непродовольчими) підприємствами роздрібної торгівлі. Так, однією із прогресивних форм об'єднань у торговельній сфері виступають торговельні мережі, що диференційовані за форматами. Можна припустити, що кількість бізнес-процесів залежить від формату і розміру підприємства роздрібної торгівлі. Керуючись такою логікою дослідження, проведемо порівняльну характеристику бізнеспроцесів різних форматів підприємств роздрібної торгівлі, результати якої подано у табл. 1.

Дослідженню підлягають підприємства роздрібної торгівлі м. Києва 3 розміром торговельної площі від $400 \mathrm{~m}^{2}$ до $1000 \mathrm{~m}^{2}$, товарооборотом від 70 млн грн, кількістю задіяного персоналу від 16 осіб, універсальною та скомбінованою формою товарної спеціалізації, низьким і середнім ціновим рівнем, домінуючим методом роздрібного продажу - самообслуговування.

У ході дослідження пропонуємо сконцентрувати увагу на основних бізнеспроцесах, що притаманні багатьом продовольчим підприємствам роздрібної торгівлі м. Києва та $є$ важливими при формуванні доданої вартості та споживчої цінності.

Таблиия 1. Бізнес-процеси підприємств роздрібної торгівлі м. Києва, власне дослідження авторів

\begin{tabular}{|c|c|c|c|c|c|c|c|c|c|c|c|c|c|c|c|}
\hline \multirow[b]{2}{*}{$\begin{array}{c}\text { Назва } \\
\text { підприємства } \\
\text { роздрібної } \\
\text { торгівлі }\end{array}$} & \multicolumn{15}{|c|}{ Бізнес-процеси підприємств роздрібної торгівлі } \\
\hline & 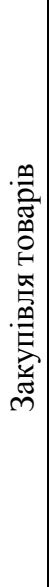 & 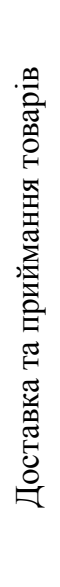 & 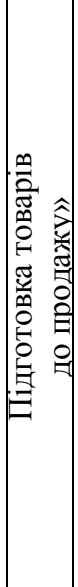 & 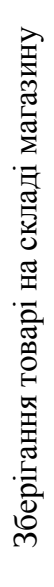 & 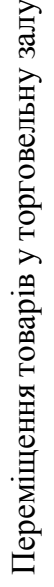 & 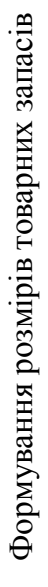 & 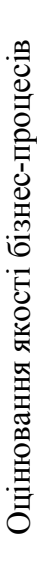 & 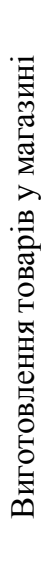 & 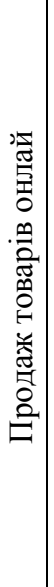 & 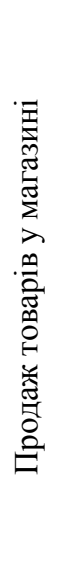 & 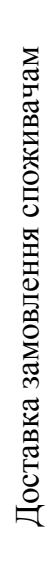 & 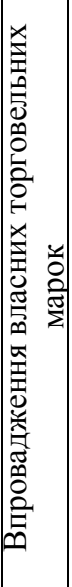 & 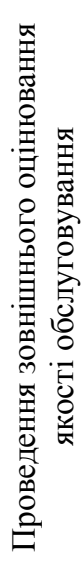 & 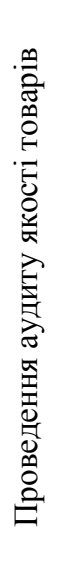 & 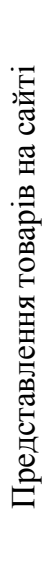 \\
\hline 1 & 2 & 3 & 4 & 5 & 6 & 7 & 8 & 9 & 10 & 11 & 12 & 13 & 14 & 15 & 16 \\
\hline $\begin{array}{c}\text { TOВ «АТБ- } \\
\text { маркет» }\end{array}$ & + & + & + & - & + & + & + & - & - & + & - & + & + & + & + \\
\hline «Білла Україна» & + & + & + & + & + & + & + & + & - & + & - & + & - & + & + \\
\hline
\end{tabular}


Продовження табл. 1.

\begin{tabular}{|c|c|c|c|c|c|c|c|c|c|c|c|c|c|c|c|}
\hline 1 & 2 & 3 & 4 & 5 & 6 & 7 & 8 & 9 & 10 & 11 & 12 & 13 & 14 & 15 & 16 \\
\hline $\begin{array}{c}\text { ТОВ } \\
\text { «Континент» }\end{array}$ & + & + & + & + & + & + & - & - & - & + & - & + & - & - & + \\
\hline $\begin{array}{c}\text { ТОВ «Рітейл } \\
\text { Центр» } \\
\text { («Фуршет») }\end{array}$ & + & + & + & + & + & + & + & + & + & + & + & + & - & + & + \\
\hline $\begin{array}{c}\text { ТОВ «Рітейл } \\
\text { Груп» («Велика } \\
\text { кишеня») }\end{array}$ & + & + & + & + & + & + & + & + & - & + & - & + & - & + & + \\
\hline ТОВ «Уагиз» & + & + & + & + & + & + & + & + & - & + & - & + & - & + & + \\
\hline $\begin{array}{c}\text { ТОВ «Еко- } \\
\text { маркет» }\end{array}$ & + & + & + & + & + & + & + & + & - & + & - & + & - & + & + \\
\hline $\begin{array}{c}\text { ТОВ «ЛІА ЛТД» } \\
\text { («Абсолют») }\end{array}$ & + & + & + & + & + & + & - & + & - & + & - & + & - & - & + \\
\hline $\begin{array}{c}\text { ТОВ «Фоззі-Фуд» } \\
\text { («Сільпо») }\end{array}$ & + & + & + & + & + & + & + & + & - & + & - & + & - & + & + \\
\hline $\begin{array}{c}\text { ТОВ «НОВУС } \\
\text { Україна }\end{array}$ & + & + & + & + & + & + & + & + & + & + & + & + & + & + & + \\
\hline ТОВ «Лоток» & + & + & + & - & + & + & + & - & - & + & - & - & - & + & + \\
\hline $\begin{array}{c}\text { ТОВ «Смарт- } \\
\text { холдинг» } \\
\text { («Амстор») }\end{array}$ & + & + & + & + & + & + & + & + & - & + & - & - & - & + & + \\
\hline $\begin{array}{c}\text { ТОВ «Фоззі-Фуд» } \\
\text { («Фора») }\end{array}$ & + & + & + & - & + & + & + & - & - & + & - & + & - & + & + \\
\hline
\end{tabular}

Авторами дослідження виявлено такі особливості бізнес-процесів підприємств роздрібної торгівлі м. Києва (залежно від формату функціонування цих підприємств):

- загальними операційними бізнес-процесами для всіх форматів підприємств роздрібної торгівлі є бізнес-процеси закупівлі товарів, прийняття товарів, їх розпакування, переміщення до торговельної зали, формування розмірів товарних запасів. Відзначимо, що бізнес-процес з підготовки товару для продажу має місце на всіх досліджуваних підприємствах;

- у магазинах формату «біля дому», «дискаунтер» майже відсутні бізнеспроцеси зберігання товарів на складі. Для універсальних магазинів характерна тенденція оптимізації складських приміщень у магазині. Найчастіше підприємства роздрібної торгівлі організують бізнес-процеси постачання товарів за технологією «крос-докінга», що передбачає прямі поставки постачальниками товарів необхідної кількості та якості у розподільчі центри торговельної мережі. У той же час товари не зберігаються у розподільчих центрах, а фасуються та розподіляються за сформованими маршрутами по магазинах. Ключовими перевагами таких складів є обслуговування декількох десятків магазинів мережі одночасно й оптимізація логістичних витрат;

- у супермаркетах підприємство 3 100\% іноземними інвестиціями «Білла Україна», TOB «Novus Україна», ТОВ «Рітейл Центр» («Фуршет»), ТОВ «Смарт-холдинг» («Амстор»), ТОВ «Varus», ТОВ «Еко-маркет», ТОВ «ЛІА ЛТД» («Абсолют»), ТОВ «Фоззі-Фуд» («Сільпо»), ТОВ «Рітейл Груп» («Велика кишеня») мають місце бізнес-процеси щодо виробництва товарів у 
магазині. В дискаунтерах «АТБ», «магазинах біля дому» ТОВ «Фоззі-Фуд» («Фора»), ТОВ «Лоток», ТОВ «Континент» у торговельній залі представлені товари власного виробництва. Такі бізнес-процеси спрямовані на залучення споживачів і диференціацію асортименту магазину;

- бізнес-процеси 3 продажу товару онлайн, доставки замовлення споживачам відбуваються в супермаркетах ТОВ «Фуршет», ТОВ «Novus Україна». Зазвичай, економічний ефект Інтернет-магазинів полягає у нарощуванні обсягів продажів. Соціальний ефект для споживачів підприємств розкривається через економію їхнього часу завдяки швидкому пошуку та купівлі товарів, не виходячи $з$ дому;

- дискаунтери ТОВ «АТБ-маркет», супермаркети ТОВ «Novus Україна» впроваджують бізнес-процеси зовнішнього оцінювання якості торговельного обслуговування споживачами. Підприємства роздрібної торгівлі, за винятком ТОВ «Абсолют», ТОВ «Континент», імплементують у діяльність бізнес-процеси експертного контролю якості товарів із залученням працівників санітарно-ветеринарної служби, співпраці з науково-дослідними лабораторіями, створення спеціалізованих департаментів якості та проводять загальне оцінювання якості бізнес-процесів;

- всі досліджувані підприємства роздрібної торгівлі використовують Інтернет-сайти, які дають змогу споживачам дистанційно ознайомлюватися з асортиментом, акційними пропозиціями на підприємствах. Проте на переважній більшості підприємств роздрібної торгівлі відсутні бізнес-процеси продажів товарів через Інтернет-мережу;

- підприємства роздрібної торгівлі, за винятком ТОВ «Лоток», ТОВ «Смарт холдінг» («Амстор»), впроваджують в асортимент товари власних торговельних марок.

Підсумовуючи вищевикладене, можна стверджувати, що, по-перше, на підприємствах роздрібної торгівлі при здійсненні управління бізнес-процесами недостатньою мірою впроваджується політика у сфері управління якістю бізнес-процесами, товарами/послугами, що на сьогодні є важливою складовою конкурентоспроможності підприємств. По-друге, в епоху інформаційних технологій виявлено прогалини в інформаційному забезпечені підприємств роздрібної торгівлі. Переважна їх більшість незначною мірою впроваджує послуги оформлення замовлень і продажу товарів через мережу Інтернет, хоча деякі з них взагалі не використовують Інтернет-сайти у своїй діяльності. По-третє, в асортименті деяких підприємств роздрібної торгівлі відсутні власні торговельні марки (ВТМ), популярність яких нині зростає серед споживчої аудиторії.

Отже, розвиток ВТМ, впровадження політики управління якістю, розвиток електронної комерції $є$ резервами підвищення показників бізнес-процесів, збільшення фінансових результатів підприємств роздрібної торгівлі.

Наступним етапом аналізу є оцінювання рівня проблемності бізнес-процесів. Також запропонуємо інструменти мінімізації проблем. Для визначення рівня проблемності бізнес-процесів доречно використовувати експертний метод. У ролі експертів було обрано керівників підприємств, спеціалістів із регламентування й опису бізнес-процесів, власників бізнес-процесів (завідувачів 
складів, керівників відділів логістики, маркетингу, продажів, департаменту якості) виконавців бізнес-процесів (комірників, продавців-консультантів, приймальників товарів). Оцінювання рівня проблемності бізнес-процесів проведено за п'ятибальною шкалою: 1 - непроблемні, 2 - мають незначні проблеми, 3 - мають значні проблеми, 4 - проблемні, 5 - критично проблемні. Розрахунок середнього балу проведемо, використовуючи метод середньої арифметичної простої. Узагальнені результати експертного оцінювання рівня проблемності бізнес-процесів продовольчих підприємств роздрібної торгівлі подано у табл. 2.

Таблиця 2. Узагальнені результати експертного оцінювання проблемності бізнеспроцесів підприсмств роздрібної торгівлі м. Кисва, власне дослідження авторів

\begin{tabular}{|c|c|c|c|c|c|c|c|c|}
\hline \multirow[b]{2}{*}{$\left|\begin{array}{c}\text { Бізнес-процеси } \\
\text { підприємств } \\
\text { роздрібної торгівлі }\end{array}\right|$} & \multirow[b]{2}{*}{$\begin{array}{l}\text { Основні проблеми } \\
\text { бізнес-процесів }\end{array}$} & \multicolumn{5}{|c|}{ Експертна оцінка у балах } & \multirow[b]{2}{*}{ 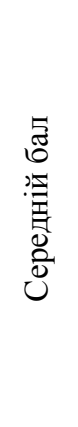 } & \multirow[b]{2}{*}{ 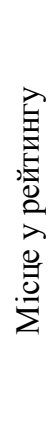 } \\
\hline & & 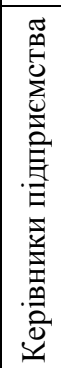 & 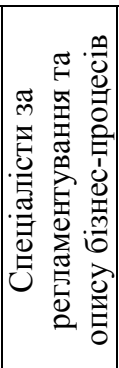 & 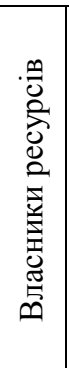 & 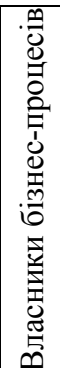 & 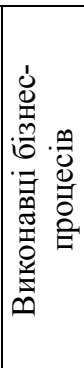 & & \\
\hline 1 & 2 & 3 & 4 & 5 & 6 & 7 & 8 & 9 \\
\hline $\begin{array}{c}\text { Продаж товарів } \\
\text { онлайн }\end{array}$ & $\begin{array}{c}\text { Низький рейтинг сайту, } \\
\text { відсутність кастомізації та } \\
\text { персоналізації бізнес-процесів }\end{array}$ & 4,9 & 4,9 & 4,8 & 4,9 & 4,9 & 4,88 & 1 \\
\hline $\begin{array}{c}\text { Продаж товарів у } \\
\text { магазині }\end{array}$ & $\begin{array}{c}\text { Сезонність, недостатня квалі- } \\
\text { фікація персоналу, коливання } \\
\text { валютного курсу, падіння } \\
\text { індексу споживчих настроїв }\end{array}$ & 4,9 & 4,9 & 4,8 & 4,9 & 4,9 & 4,88 & 1 \\
\hline \begin{tabular}{|c|} 
Зберігання товарів \\
на складах магазину
\end{tabular} & $\begin{array}{l}\text { Висока вартість зберігання; } \\
\text { псування товарів на складах }\end{array}$ & 4,9 & 4,9 & 4,7 & 4,9 & 4,9 & 4,86 & 1 \\
\hline $\begin{array}{l}\text { Представлення } \\
\text { товарів на сайті }\end{array}$ & $\begin{array}{c}\text { Високі витрати на розвиток } \\
\text { сайту, низька відвідуваність, } \\
\text { низький коефіцієнт конверсії, } \\
\text { низький рівень автоматизації } \\
\text { бізнес-процесів }\end{array}$ & 4,9 & 4,9 & 4,7 & 4,8 & 4,9 & 4,84 & 1 \\
\hline $\begin{array}{c}\text { Виготовлення } \\
\text { товарів у магазині }\end{array}$ & $\begin{array}{c}\text { Постачання неякісної } \\
\text { сировини, псування } \\
\text { вироблених товарів у магазині } \\
\end{array}$ & 4,7 & 4,8 & 4,9 & 4,9 & 4,9 & 4,84 & 1 \\
\hline $\begin{array}{c}\text { Доставка } \\
\text { замовлення } \\
\text { споживачам }\end{array}$ & $\begin{array}{c}\text { Високі витрати палива, витрати } \\
\text { на укладання договорів } 3 \\
\text { логістичними компаніями }\end{array}$ & 4,7 & 4,8 & 4,6 & 4,9 & 4,7 & 4,74 & 1 \\
\hline $\begin{array}{c}\text { Доставка та } \\
\text { приймання товарів }\end{array}$ & \begin{tabular}{|c|} 
Дефіцит кваліфікованих \\
персоналу, низька якість \\
торговельного обслуговування, \\
нерегламентовані операції \\
\end{tabular} & 4,7 & 4,7 & 4,6 & 4,8 & 4,7 & 4,71 & 1 \\
\hline $\begin{array}{c}\text { Підготовка товарів } \\
\text { до продажу }\end{array}$ & \begin{tabular}{|c|} 
Застаріле торговельно- \\
технологічне обладнання
\end{tabular} & 4,7 & 4,7 & 4,6 & 4,8 & 4,7 & 4,71 & 1 \\
\hline
\end{tabular}


Продовження табл. 2.

\begin{tabular}{|c|c|c|c|c|c|c|c|c|}
\hline 1 & 2 & 3 & 4 & 5 & 6 & 7 & 8 & 9 \\
\hline $\begin{array}{c}\text { Переміщення } \\
\text { товарів у } \\
\text { торговельну залу }\end{array}$ & $\begin{array}{l}\text { Застаріле торговельно- } \\
\text { технологічне обладнання }\end{array}$ & 4,5 & 4,5 & 4,6 & 4,5 & 4,3 & 4,48 & 1 \\
\hline $\begin{array}{l}\text { Оцінювання якості } \\
\text { бізнес-процесів }\end{array}$ & \begin{tabular}{|c|} 
Отримання від постачальників \\
неякісних (бракованих) товарів, \\
невідповідність отриманих \\
товарів стандартам \\
\end{tabular} & 4,3 & 4,5 & 4,3 & 4,5 & 4,3 & 4,38 & 2 \\
\hline $\begin{array}{c}\text { Проведення } \\
\text { зовнішнього } \\
\text { оцінювання якості } \\
\text { обслуговування } \\
\end{array}$ & $\begin{array}{c}\text { Витратність, відсутність } \\
\text { електронних пристроїв щодо } \\
\text { оцінювання споживачами } \\
\text { якості обслуговування }\end{array}$ & 4,3 & 4,3 & 4,3 & 4,4 & 4,3 & 4,32 & 2 \\
\hline $\begin{array}{l}\text { Проведення аудиту } \\
\text { якості товарів }\end{array}$ & $\begin{array}{c}\text { Відсутність системи показників } \\
\text { оцінювання якості, брак } \\
\text { кваліфікованих фахівців }\end{array}$ & 4,3 & 4,3 & 4,3 & 4,1 & 4,2 & 4,24 & 2 \\
\hline Закупівля товарів & $\begin{array}{c}\text { Коливання валютного курсу, } \\
\text { невиконання всіх умов } \\
\text { договору }\end{array}$ & 3,2 & 3,8 & 4,2 & 4,3 & 4,2 & 3,94 & 3 \\
\hline $\begin{array}{c}\text { Формування } \\
\text { розмірів товарних } \\
\text { запасів }\end{array}$ & $\begin{array}{c}\text { Низька ліквідність деяких груп } \\
\text { товарних запасів, низька } \\
\text { купівельна спроможність } \\
\text { населення країни }\end{array}$ & 3,2 & 3,8 & 4,1 & 4,1 & 4,2 & 3,88 & 3 \\
\hline $\begin{array}{c}\text { Впровадження } \\
\text { ВТМ }\end{array}$ & $\begin{array}{c}\text { Висока конкуренція з боку } \\
\text { брендів, низька лояльність } \\
\text { споживачів }\end{array}$ & 3,9 & 4,1 & 2,8 & 3,4 & 4,2 & 3,68 & 4 \\
\hline
\end{tabular}

Подальший аналіз бізнес-процесів продовольчих підприємств роздрібної торгівлі м. Києва пропонуємо проводити, об’єднавши їх у чотири групи, що дасть змогу спростити дослідження.

Таким чином, у результаті оцінювання рівня проблемності можна виділити такі групи бізнес-процесів підприємств роздрібної торгівлі м. Києва:

- торговельно-технологічні бізнес-процеси $є$ основою доведення товарів до споживачів. Вони починаються з операцій приймання товарів і закінчуються операціями касового розрахунку, тому негативними наслідками невирішених проблем у цих бізнес-процесах $є$ незадоволений споживчий попит, зниження обсягів товарообороту та прибутку підприємств роздрібної торгівлі;

- бізнес-процеси поліпшення якості обслуговування $є$ одними із пріоритетних бізнес-процесів для споживачів і персоналу підприємств роздрібної торгівлі. Проблеми в цих бізнес-процесах знижують якість продукції, створюють прогалини в репутації та іміджі підприємства;

- закупівельні, що включають бізнес-процеси формування товарних запасів, дають змогу підприємствам роздрібної торгівлі своєчасно забезпечувати споживачів товарами необхідної якості та кількості. Також вони $\epsilon$ початком для інших бізнес-процесів підприємств. Виникнення проблем у цих бізнес-процесах призводить до порушення перебігу торговельно-технологічних бізнес-процесів підприємств роздрібної торгівлі;

- маркетингові бізнес-процеси, до складу яких входять бізнес-процеси впровадження та розвитку ВТМ, є одними 3 операційних бізнес-процесів під- 
приємств роздрібної торгівлі. Своєчасне діагностування та вирішення проблем у маркетингових бізнес-процесах дає змогу поглибити ринкові можливості підприємств і підвищити лояльність споживачів до торговельної мережі.

Дослідження бізнес-процесів продовольчих підприємств роздрібної торгівлі м. Києва дасть змогу виявити найбільш поширені, на думку експертів, проблеми, що виникають при їх реалізації. Досягнення поставленої мети здійснимо за п'ятибальною шкалою: 1 - відсутні; 2 - не поширені; 3 іноді виникають; 4 - поширені; 5 - дуже поширені. Узагальнені результати дослідження проблем, що виникають при реалізації бізнес-процесів продовольчих підприємств роздрібної торгівлі, представлено на рисунку.

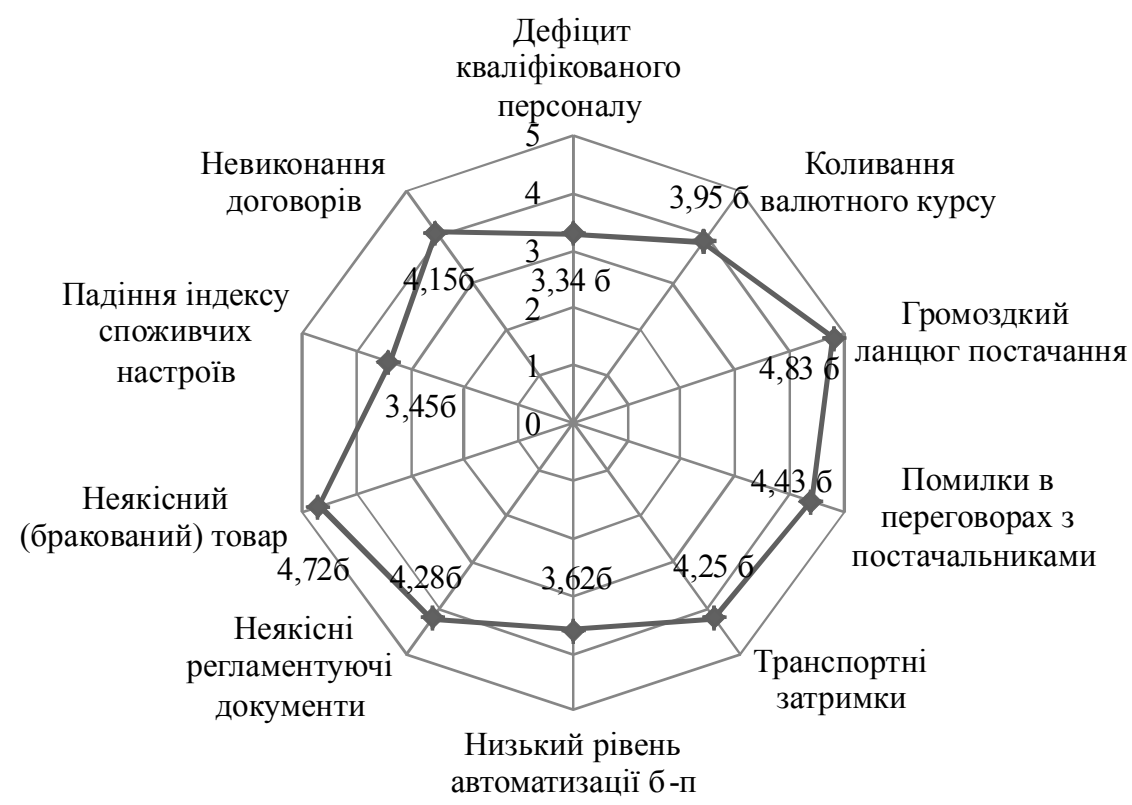

Рис. Проблеми, що виникають при реалізації бізнес-процесів продовольчих підприємств роздрібної торгівлі м. Києва у 2016 році

Так, з рис. 1 можна побачити, що найбільш поширеними проблемами для продовольчих підприємств роздрібної торгівлі м. Києва $є$ громіздкий ланцюг постачання (4,83 бала), неякісний (бракований) товар (4,72 бала), помилки в переговорах 3 постачальниками (4,43 бала), неякісні регламентуючі документи (4,28 бала), транспортні затримки (4,25 бала). Безперечно, ці проблеми потребують своєчасного реагування 3 боку керівництва підприємств i термінового їх усунення, оскільки їх негативними наслідками $є$ відсутність товару на полицях, падіння обсягів товарообороту, зниження лояльності споживачів, втрачання конкурентних переваг тощо.

Враховуючи вищевикладене, автори дослідження вважають доцільним обгрунтувати заходи вдосконалення проблемних бізнес-процесів підприємств роздрібної торгівлі м. Києва (табл. 3). 
Таблиця 3. Заходи мінімізації проблем бізнес-процесів підприємств роздрібної торгівлі м. Києва

\begin{tabular}{|c|c|c|c|}
\hline $\begin{array}{c}\text { Групи } \\
\text { БП ПРТ }\end{array}$ & $\begin{array}{c}\text { Середня } \\
\text { кількісна } \\
\text { оцінка, бали }\end{array}$ & $\begin{array}{l}\text { Якісна } \\
\text { оцінка }\end{array}$ & $\begin{array}{c}\text { Заходи щодо мінімізації проблем (вдосконалення) } \\
\text { бізнес-процесів ПРТ }\end{array}$ \\
\hline \multirow{8}{*}{ 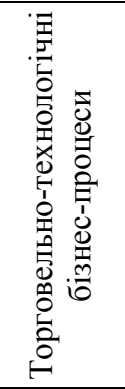 } & \multirow{8}{*}{4,77} & \multirow{8}{*}{ 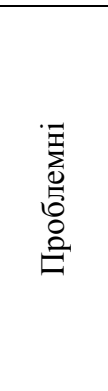 } & Аналіз операцій і моніторинг контрольних точок \\
\hline & & & $\begin{array}{c}\text { Впровадження інновацій (smart-візочки, мобільні } \\
\text { додатки та ін.) }\end{array}$ \\
\hline & & & Встановлення сучасного торговельного обладнання \\
\hline & & & Встановлення сучасних світлових технологій \\
\hline & & & Розробка регламентуючої документації \\
\hline & & & Управління асортиментом за категоріями \\
\hline & & & Участь підприємств у тендерах \\
\hline & & & $\begin{array}{c}\text { Залучення фахівців-психологів при розробці упаковки, } \\
\text { товарного знака для власних торговельних марок }\end{array}$ \\
\hline \multirow{5}{*}{ 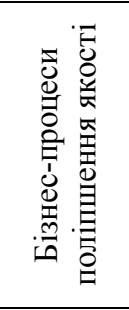 } & \multirow{5}{*}{4,3} & \multirow{5}{*}{$\begin{array}{l}\text { E } \\
\sum_{0} \\
0 \\
0 \\
0 \\
0 \\
0\end{array}$} & $\begin{array}{c}\text { Розробка інструкцій зберігання і транспортування } \\
\text { кожної групи товарів }\end{array}$ \\
\hline & & & Перевірка температурних режимів при зберіганні товарів \\
\hline & & & $\begin{array}{c}\text { Створення єдиної бази даних з відомостями про } \\
\text { постачальників } \\
\end{array}$ \\
\hline & & & Систематичне навчання персоналу \\
\hline & & & $\begin{array}{l}\text { Створення відділу аудиту контролю якості товарів або } \\
\text { залучення спеціалістів санітарно-ветеринарної служби }\end{array}$ \\
\hline \multirow{11}{*}{ 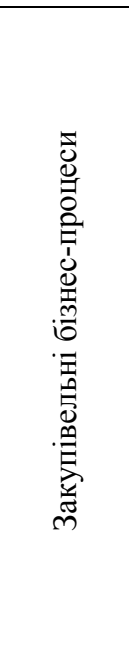 } & \multirow{11}{*}{3,91} & \multirow{11}{*}{ 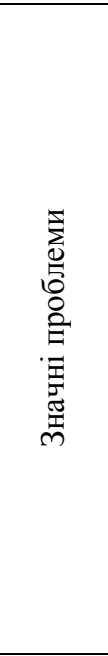 } & $\begin{array}{c}\text { Формування системи показників для вибору } \\
\text { постачальників }\end{array}$ \\
\hline & & & $\begin{array}{c}\text { Автоматизація бізнес-процесів, що дасть змогу } \\
\text { мінімізувати проблеми, пов'язані з людським фактором. }\end{array}$ \\
\hline & & & $\begin{array}{c}\text { Вертикальна комплектація товарів при перевезенні } \\
\text { забезпечить оптимізацію площ транспорту }\end{array}$ \\
\hline & & & Моніторинг постачальників і цін на товари \\
\hline & & & Впровадження Lean-технологій \\
\hline & & & $\begin{array}{c}\text { Гнучкість маршрутів доставки товарів, зменшення } \\
\text { обсягів палива }\end{array}$ \\
\hline & & & Передача бізнес-процесів на аутсорсинг \\
\hline & & & $\begin{array}{c}\text { Проведення аналізу товарних запасів } 3 \text { урахуванням } \\
\text { сезонності попиту }\end{array}$ \\
\hline & & & Проведення аналізу товарообігу підприємств \\
\hline & & & Використання сучасного обладнання \\
\hline & & & $\begin{array}{c}\text { Розробка політики управління товарними запасами та } \\
\text { оцінювання їі ефективності }\end{array}$ \\
\hline \multirow{7}{*}{ 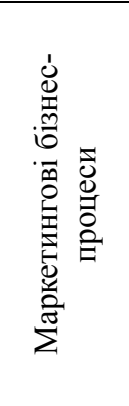 } & \multirow{7}{*}{3,68} & \multirow{7}{*}{ 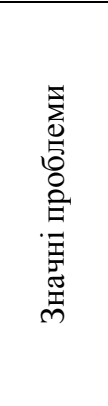 } & Грамотна презентація товарів \\
\hline & & & $\begin{array}{c}\text { Впровадження концепцій LIM (LessisMore - менше } \\
\text { значить більше), MIL (Massinlimits) }\end{array}$ \\
\hline & & & Впровадження концепцій Show Store \\
\hline & & & Ефективна маркетингова стратегія \\
\hline & & & $\begin{array}{c}\text { Розвиток СМТ в асортименті магазину як критерію } \\
\text { індивідуальності підприємства }\end{array}$ \\
\hline & & & Участь підприємств роздрібної торгівлі в тендерах \\
\hline & & & $\begin{array}{c}\text { Залучення фахівців-психологів при розробці упаковки, } \\
\text { товарного знака для власних торговельних марок }\end{array}$ \\
\hline
\end{tabular}


Підсумовуючи розглянуте, зазначимо, що теорія та практика управління перебуває у розвитку. Тому запропоновані авторами дослідження заходи щодо удосконалення бізнес-процесів підприємств роздрібної торгівлі не $є$ еталонним. Його перелік може бути доповнено/зменшено залежно від пріоритетів керівників, формату магазину, наявності фінансових ресурсів, характеру та рівня проблем бізнес-процесів підприємств роздрібної торгівлі.

\section{Висновки}

Як свідчить практичний досвід, якісний аналіз доцільно використовувати при дослідженні бізнес-процесів будь-яких підприємств роздрібної торгівлі, незалежно від їх спеціалізації, форматів, мережевої форми об'єднань, кількості бізнес-процесів, географічного розміщення, фінансового стану тощо. Разом з цим, розуміючи сутність, оперуючи інструментами та методами якісного аналізу, підприємства роздрібної торгівлі мають можливість оперативно виявляти проблемні бізнес-процеси та основні проблеми, що в них виникають. Це дає змогу керівництву приймати ефективні управлінські рішення та застосовувати адекватні заходи, мінімізуючи при цьому втрати та ризики торговельної діяльності.

Предмет подальших наукових досліджень може бути пов'язаний із розумінням сутності, ознайомленням та використанням методів кількісного аналізу бізнес-процесів підприємств роздрібної торгівлі, що дасть змогу поглибити дослідження в цьому напрямі та об'єктивно визначити резерви підвищення ефективності управління підприємствами.

\section{Лiтература}

1. Роздрібна торгівля України у 2015 році на 1 січ. 2016 р. : стат. зб. - Київ : Держ. служба стат. України, 2016. - 135 с.

2. Статистичний щорічник України за 2014 р. : стат. зб. - Київ : Держ. служба стат. України, 2015. - 585 с.

3. Державна служба статистики України [Електроний ресурс]. - Режим доступу : http://www.ukrstat.gov.ua/.

4. Бланк И.А. Торговый менеджмент / И.А. Бланк. — 2-е изд., перераб. и доп. - Киев : Эльга, Ника-Центр, 2013. - 784 с.

5. Бай C.I. Розвиток організації: політика, потенціал, ефективність : монографія / С.I. Бай. Київ : Київ. нац. торг.-екон. ун-т, 2009. — 280 с.

6. Берман Б. Розничная торговля: стратегический подход / Б. Берман, Дж. Эванс ; пер. с англ. - Москва, 2003. - 1183 с.

7. Шредер $K$. Специализированный магазин: как построить прибыльный бизнес в розничной торговле / К. Шредер ; пер. с англ. — Москва : Альпина Бизнес Букс, 2004. — 384 с.

8. Шеер Август-Вильгельм Моделирование бизнес-процессов Изд. 2-е, Перевод с англ. Каменнова М.С.Громов А.И. / Весть-МетаТехнология: — Москва, 2000. — 173 с.

9. Редченко K.I. Управління бізнес-процесами підприємств роздрібної торгівлі : монографія / К.І. Редченко, Л.О. Гелей. — Львів : СПОЛОМ, 2015. — 224c.

10. Парсяк В.Н. Управління бізнес-процесами - інструмент підвищення ефективності організацій / В.Н. Парсяк // Актуальні проблеми економіки. - 2011. - № 7(21) C. $131-138$.

11. Пономаренко В.С. Теорія та практика моделювання бізнес-процесів : монографія / В.С. Пономаренко, С.В. Мінухін, С.В. Знахур. - Харків : Вид. ХНЕУ, 2013. - 244 с.

12. Бъёрн Андерсен Бизнес-процессы. Инструменты совершенствования / А. Бьёрн ; пер. с англ. — Москва : ИНФРА-М, 2005. — 319 с. 